\title{
Isolation and detection of Mycobacterium avium subsp. paratuberculosis (MAP) from cattle in Ireland using both traditional culture and molecular based methods
}

\author{
Pierre E Douarre ${ }^{1}$, William Cashman², Jim Buckley², Aidan Coffey ${ }^{1}$, Jim M O'Mahony ${ }^{1 *}$
}

\begin{abstract}
Background: Mycobacterium avium subsp. paratuberculosis (MAP) causes a chronic gastroenteritis affecting many species. Johne's disease is one of the most widespread and economically important disease of ruminants. Since 1992 and the opening of the European market, the exposure and the transmission of MAP in cattle herds considerably increased. Improvements in diagnostic strategies for Ireland and elsewhere are urgently required. In total, 290 cattle from seven Irish herds with either a history or a strong likelihood of paratuberculosis infection were selected by a veterinary team over 2 years. Faecal samples (290) were collected and screened for MAP by a conventional culture method and two PCR assays. In order to further evaluate the usefulness of molecular testing, a nested PCR was also assessed.

Results: M. paratuberculosis was isolated and cultured from 23 faecal samples (7.9\%) on solid medium. From a molecular perspective, 105 faecal samples (36\%) were PCR positive for MAP specific DNA. A complete correlation (100\%) was observed between the results of both molecular targets (IS900 and ISMAP02). Sensitivity was increased by $~ 10 \%$ with the inclusion of a nested PCR for ISMAP02 (29 further samples were positive). When culturing and PCR were retrospectively compared, every culture positive faecal sample also yielded a PCR positive result for both targets. Alternatively, however not every PCR positive sample $(n=105,36 \%)$ produced a corresponding culture isolate. Interestingly though when analysed collectively at the herd level, the correlation between culture and PCR results was 100\% (ie every herd which recorded at least 1 early PCR +ve result later yielded culture positive samples within that herd).

Conclusion: PCR on bovine faecal samples is a fast reliable test and should be applied routinely when screening for MAP within herds suspected of paratuberculosis. Nested PCR increases the threshold limit of detection for MAP DNA by approximately $10 \%$ but proved to be problematic in this study. Although slow and impractical, culturing is still regarded as one of the most reliable methods for detecting MAP among infected cattle.
\end{abstract}

\section{Background}

Johne's disease caused by Mycobacterium avium subsp. paratuberculosis (MAP), is one of the most widespread and economically important disease of ruminants. It is a chronic granulomatous enteritis affecting primarily ruminants and many other species [1], which is characterised by persistent diarrhoea, weight loss and a protein

\footnotetext{
* Correspondence: jim.omahony@cit.ie

${ }^{1}$ Cork Institute of Technology, Bishopstown, Cork, Ireland

Full list of author information is available at the end of the article
}

enteropathy, followed eventually by death [2]. Most cattle are infected early in life by the ingestion of faeces, milk or MAP contaminated water. The relatively long incubation period is characterized by the excretion of MAP in faeces for months and years before clinical symptoms develop [3]. The exposure to contaminated faeces constitutes one of the main risk factors for MAP transmission within the herd.

Johne's disease causes worldwide economic losses to farmers and dairy industries in terms of milk and meat production. It is considered a serious disease for dairy 
cattle as there is no effective treatment and it's control is difficult due to the long latent period. In dairy herds, losses are associated with reduced milk yield and weight gain, lower reproductive efficiency, premature culling and reduced values of culled cattle [4]. The effect of paratuberculosis on dairy operations in the USA was estimated at around $\$ 200$ to $\$ 250$ million a year [5].

Paratuberculosis has been a scheduled and notifiable disease in Ireland since 1955. Prior to the $1990 \mathrm{~s}$, the low number of notified clinical cases (only 92 diagnosed between 1932 to 1992, mostly in imported animals) indicated that MAP wasn't widely established in the country. The importation of 85,000 cattle from continental Europe between 1992 and 2004 (Central Statistics Office, personal communication) as a consequence of the opening of the single European market in 1992 coincided with an increase in the prevalence of MAP infection in Ireland. Recent studies have shown that the risk of MAP exposure and transmission increases annually [6]. Between 1995 and 2002, 232 animals infected with MAP among 106 Irish herds were reported [7]. Also, in 2005, the seroprevalence of infected herds in Ireland was found to be $21.4 \%$ [8]. Currently, the prevalence of paratuberculosis among herds in Ireland is lower than that reported in many countries in Europe (Denmark $55 \%$, France $68 \%$ and Netherlands 54\%) [9] probably because of the late introduction and establishment of JD in Ireland. However it is likely that the prevalence in Ireland will continue to rise to match rates seen elsewhere, unless appropriate preventive and control measures are taken.

Similarities between Johne's disease in ruminants and Crohn's Disease (CD) in humans [10] as well as studies which identified MAP in CD's patient [11] have led to speculation that MAP may be a aetiological agent in Crohn's disease. Many reports showed the pathogenesis of $C D$ is complex and multi-factorial with genetic and environmental contributions $[12,13]$. The causative link between MAP and CD is still controversial and the zoonotic potential of MAP remains a subject of debate [14]. The identification of viable MAP in pasteurized milk $[15,16]$ and meat [17] should be regarded as a significant issue in terms of bio-security.

Detecting the presence of MAP is difficult because of the slow growth and the lack of sensitive tests to identify subclinically infected cattle. Specific and sensitive diagnostic tools as well as a better understanding of the pathogenesis of JD are needed to develop control programs to eradicate the disease.

This study was carried out on bovine faecal samples from 7 Irish herds which either had a history of or a likely exposure to MAP within 2 years of this study. The aim of this project was to evaluate a diagnostic strategy for MAP in targeted Irish herds. Specifically, we set out to compare a conventional culturing method with PCR, to evaluate the reliability of 2 different molecular targets and finally, to assess the improved sensitivity of a nested PCR assay.

\section{Methods}

\section{Sample collection}

290 individual bovine faecal samples were collected over 2 years (11/06 to 10/08) from 7 Irish herds which were strategically selected by a veterinary team. The location, the type of the herd, the breed and number of animals from each sampling period are summarized in Table 1. All the faecal samples were from individual animals, and were kept at $4^{\circ} \mathrm{C}$ up to 48 hours prior to processing for culture and DNA extraction. The strategy designed to process the samples is described in Figure 1.

\section{Sample preparation and culture}

A modified centrifugation method was used to cultivate MAP [18]. Briefly, one gram of faeces was added to $20 \mathrm{ml}$ of sterile distilled water, tubes were vortexed for $1 \mathrm{~min}$ and then allowed to stand undisturbed for $30 \mathrm{~min}$. Five $\mathrm{ml}$ of the supernatant were added to $25 \mathrm{ml}$ of $0.9 \%$ hexadecylpyridinium chloride (HPC) and allowed to stand undisturbed overnight at room temperature. Tubes were centrifuged at $1700 \mathrm{~g}(4300 \mathrm{rpm})$ for $20 \mathrm{~min}$, the supernatant was decanted and the pellet was resuspended in $1 \mathrm{ml}$ of $50 \mu \mathrm{g} / \mathrm{ml}$ amphotericin B. HEYM agar containing vancomycin, nalidixic acid and amphotericin B at $50 \mu \mathrm{g} / \mathrm{ml}$ were inoculated with $0.2 \mathrm{ml}$ of the suspension and incubated in sealed $25 \mathrm{~cm}^{3}$ tissue culture flasks (Sarstedt) at $37^{\circ} \mathrm{C}$ for 24 weeks.

\section{Confirmation of cultured mycobacteria}

Slow growth rate and typical colony morphology was first observed before checking for acid fast bacteria and

Table 1 Information on the selected herds

\begin{tabular}{|c|c|c|c|c|c|c|}
\hline $\begin{array}{l}\text { Herd } \\
\text { Id }\end{array}$ & Location & Type & $\begin{array}{c}\text { No. } \\
\text { animals }\end{array}$ & Breed & $\begin{array}{c}\text { Sample } \\
\text { date }\end{array}$ & $\begin{array}{l}\mathbf{n} \\
=\end{array}$ \\
\hline $\mathrm{H1}$ & Munster & Beef & 140 & ${ }^{\mathrm{a}}$ Mix & $11 / 2006$ & 4 \\
\hline $\mathrm{H} 1$ & Munster & $"$ & $"$ & $"$ & 05/2007 & 22 \\
\hline $\mathrm{H} 2$ & Munster & Dairy" & $180^{\prime \prime}$ & $\begin{array}{c}\text { Holstein } \\
\text { Fr" }^{\prime \prime}\end{array}$ & 05/2007 & 44 \\
\hline $\mathrm{H} 2$ & Munster & & & & $04 / 2008$ & 73 \\
\hline $\mathrm{H} 3$ & Munster & Dairy & 630 & Holstein Fr & 07/2007 & 35 \\
\hline $\mathrm{H} 4$ & Ulster & Beef & 200 & Mix* & 07/2007 & 62 \\
\hline $\mathrm{H} 5$ & Munster & Dairy & 150 & Holstein Fr & $04 / 2008$ & 17 \\
\hline $\mathrm{H} 6$ & Munster & Dairy & 150 & Holstein $\mathrm{Fr}$ & 04/2008 & 2 \\
\hline $\mathrm{H} 7$ & Munster & Dairy & $"$ & Holstein $\mathrm{Fr}$ & $10 / 2008$ & 31 \\
\hline
\end{tabular}

Herd identification, location, type, breed and number of animals as well as the date and the number of samples tested.

${ }^{a}$ mix of Charolais, Herford and Simmental breeds.

$\mathrm{n}=$ number of samples tested 


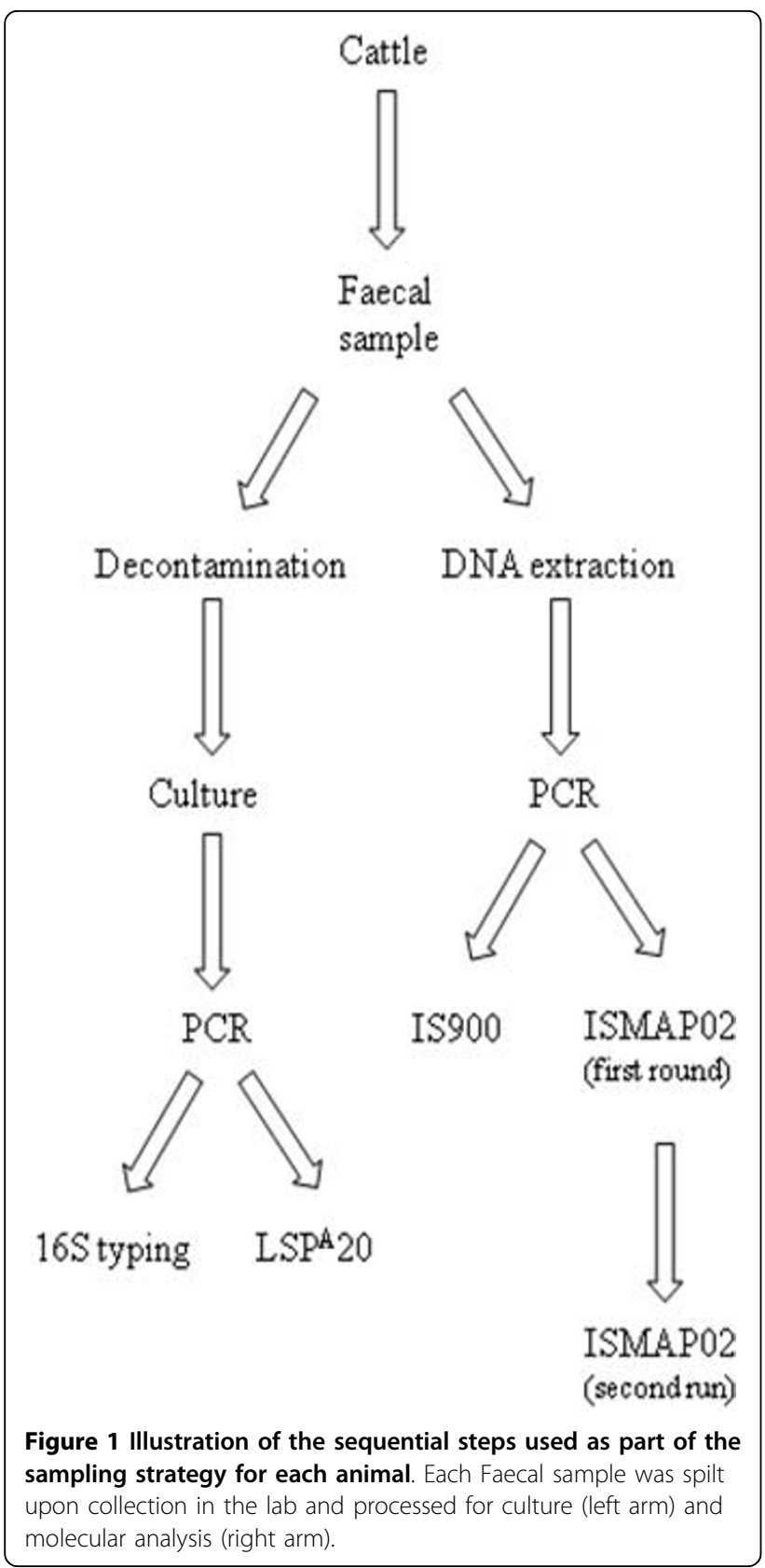

mycobactin dependency. Confirmation of the mycobacterial species was established by $16 \mathrm{~S}$ typing [19] and the presence of the MAP bovine specific large sequence polymorphism $\mathrm{LSP}^{\mathrm{A}} 20$ was detected by PCR [20]. In order to generate sufficient biomass, a single colony of each confirmed MAP isolate was subcultured into 7H9 broth supplemented with OADC and Mycobactin J and incubated at $37^{\circ} \mathrm{C}$. Individual colonies from faster growing mycobacteria which were isolated during the sampling periods were also analysed by $16 \mathrm{~S}$ typing as above.

As this study was designed to compare culturing with PCR, a representative sample from the same faecal sample was removed and processed as outlined below (see Figure 1):

\section{DNA extraction from faeces}

One gram of faecal sample was added to $5 \mathrm{ml}$ of $10 \mathrm{mM}$ $\mathrm{TE}(\mathrm{pH} 8.0)$, which was vortexed for $1 \mathrm{~min}$ and then allowed to stand undisturbed for $30 \mathrm{~min} .750 \mu \mathrm{L}$ of the supernatant was transferred to a $2 \mathrm{ml}$ screw capped tube containing acid washed glass beads (Sigma, G1145) and $750 \mu \mathrm{l}$ of fresh GITC lysis buffer $(50 \mathrm{mM}$ tris $\mathrm{HCl}$, 10 mM EDTA, 2\%Triton X-100, 4 M GITC, $0.3 \mathrm{M}$ sodium Acetate) [21]. The samples were sheared in a Ribolyser (MagNA Lyser, Roche) for $45 \mathrm{sec}$ at $6500 \mathrm{~m} \cdot \mathrm{s}^{-1}$ and then boiled for $5 \mathrm{~min}$. The tubes were then spun at $12000 \mathrm{rpm}$ and the supernatant was transferred to a fresh tube. The disrupted cell extract was then mixed with an equal volume of phenol:chloroform:isoamyl alcohol 25.24.1. The samples were shaken manually for $5 \mathrm{~min}$ and centrifuged at $12000 \mathrm{rpm}$ for $10 \mathrm{~min}$. The aqueous layer was transferred to a fresh tube containing an equal volume of chloroform:isoamyl alcohol and shaken for $5 \mathrm{~min}$. Following centrifugation at $12000 \mathrm{rpm}$ for $10 \mathrm{~min}$, the DNA was precipitated with $2 \mathrm{Vol}$ of $100 \%$ ethanol and $0.5 \mathrm{Vol}$ of ammonium acetate $(7 \mathrm{M})$ at $-20^{\circ} \mathrm{C}$ overnight. After 2 washes with $70 \%$ ethanol, the DNA pellet was dried and resuspended with $50 \mu 110 \mathrm{mM}$ TE buffer.

\section{IS900 PCR}

Samples were analysed by real time PCR targeting the IS900 element, using the method of O'Mahony (2002), [22] with modifications. Primer sequences for the amplification were 5'-GAAGGGTGTTCGGGGCCGTCGCTTAGG-3' and 5'-GGCGTTGAGGTCGATCGCCC ACGTGAC-3' (reverse primer) and generated a $400 \mathrm{bp}$ product. The reaction mixture consisted of $2 \times$ LightCycler $^{\circ} 480$ SYBR Green I Master (Roche) (containing the FastStart Taq DNA Polymerase, reaction buffer, dNTP mix, SYBR Green I dye and $\mathrm{MgCl} 2$ ), $0.5 \mu \mathrm{M}$ of each primer and PCR grade water. Sample tubes contained $5 \mu \mathrm{l}$ of faecal extract DNA. Controls consisted of reaction mixture alone (negative control) and a positive control containing $1 \mu \mathrm{l}$ of genomic DNA from $M$. avium subsp. paratuberculosis (strain 19698). Samples were run according to the following conditions: 1 cycle at $95^{\circ} \mathrm{C}$ for $10 \mathrm{~min}$ and 35 cycles at $95^{\circ} \mathrm{C}$ for $10 \mathrm{~s}, 60^{\circ} \mathrm{C}$ for $10 \mathrm{~s}$, and $72^{\circ} \mathrm{C}$ for $16 \mathrm{~s}$. All PCR positive samples were then assessed by melting curve profile and conventional gel analysis.

\section{ISMAP02 PCR}

Samples were run by using a real-time PCR targeting ISMAP02, a modified method of the PCR described by Stabel and Bannantine (2005), [23]. Specific primer sequences for the initial amplification were 
5'-GCACGGTTTTTCGGATAACGAG-3' and 5'-TCA ACTGCGTCACG GTGTCCTG-3' and generated a 278 bp product. The reaction mixture, samples and controls with the exception of the primers were prepared as described for the IS900 PCR. Samples were run according to the following conditions: 1 cycle at $95^{\circ} \mathrm{C}$ for $10 \mathrm{~min}$ and 35 cycles at $95^{\circ} \mathrm{C}$ for $10 \mathrm{~s}, 58^{\circ} \mathrm{C}$ for $10 \mathrm{~s}$, and $72^{\circ} \mathrm{C}$ for $12 \mathrm{~s}$. PCR results were confirmed as described above for the IS900 PCR.

\section{ISMAP02 Nested PCR}

To evaluate the performance of a nested real-time PCR, the products resulting from the initial ISMAP02 PCR were re-tested by a second set of primers. The nested primers used for this second amplification reaction were 5'-GGATAACGAGACCGTGGATGC $-3^{\prime}$ and 5'-AACCGACGCCGCCAATACG-3' and yielded a 117 bp product. The reaction mixture, samples and controls were prepared as above. One $\mu \mathrm{l}$ of the amplicon from the first PCR was used as the template for the second amplification: 1 cycle at $95^{\circ} \mathrm{C}$ for $10 \mathrm{~min}$ and 30 cycles at $95^{\circ} \mathrm{C}$ for $10 \mathrm{~s}, 60^{\circ} \mathrm{C}$ for 10 , and $72^{\circ} \mathrm{C}$ for $5 \mathrm{~s}$. The size of the PCR amplicons was then confirmed as described above. To confirm (eliminate false positives) ISMAP02 nested PCR positive results, two alternative nested PCRs targeting IS900 (TJ1-4) [11] and F57 [24] were carried out on separate DNA extracts from samples which were ISMAP02 nested PCR positive.

\section{Results}

Isolation of viable mycobacteria by culturing

The culture results for all 290 faecal samples tested during this study are summarized in Table 2. MAP was cultured from 23 of the 290 samples tested (7.9\%). Four herds $(\mathrm{H} 1, \mathrm{H} 2, \mathrm{H} 3$ and $\mathrm{H} 4)$ were positive for MAP culture with at least 2 samples positive from each herd while the other 3 herds (H5,H6 \& H7) were MAP culture negative. The percentage of MAP positive culture ranged from $3 \%$ (herd $\mathrm{H} 4$ ) to $75 \%$ (herd $\mathrm{H} 1,2006$ ). The first 4 samples collected in 2006 from the herd H1 showed the highest percentage of culture positives and the presence of MAP in this herd was confirmed with the second batch, where typical MAP colonies were detected on solid media for 7 samples (30\%). In relation to $\mathrm{H} 2,13.6 \%$ of samples tested in the first batch were MAP positive. The 73 samples tested 10 months later from the same herd were MAP culture negative but positive for other mycobacteria (18 isolates) as seen in Table 2. Using $16 \mathrm{~S}$ rRNA gene typing 17 samples were identified as Mycobacterium non-chromogenicum and 1 Mycobacterium terrae. Five cultures from herd H3 were confirmed to be MAP positive and only 2 samples (3.2\%) in herd H4 showed MAP colonies indicating only a small number of viable MAP. Furthermore, MAP wasn't cultivated from samples recovered from herds $\mathrm{H} 5, \mathrm{H} 6$ and $\mathrm{H} 7$ but 4 other mycobacterial isolates were isolated in herd H5 (2 M. non-chromogenicum; 1 M. hiberniae) and H6 (1 M. non-chromogenicum).

\section{IS900 PCR}

The PCR results on the faecal extract DNA is summarized in Table 2. The IS900 target was detected in 105 samples representing $36 \%$ of the 290 samples tested. This target was detected in 4 herds $\mathrm{H} 1, \mathrm{H} 2, \mathrm{H} 3$ and $\mathrm{H} 4$, which correlates with the herd culture positivity rate. The percentage of positive samples varied from 100\% (Herd $\mathrm{H} 1$ and $\mathrm{H} 2$ ) to $34 \%$ (herd H4). PCR-positive results were found in all 26 samples $(100 \%)$ collected in herd H1 in 2006 and 2007. Similarly, all 44 samples tested (100\%) from herd H2 were PCR positive in 2006.

Table 2 PCR and Culture Results

\begin{tabular}{|c|c|c|c|c|c|c|c|}
\hline \multirow{3}{*}{ Herd Id } & \multirow{3}{*}{ Sampling } & \multirow{3}{*}{ No. of samples } & \multicolumn{5}{|c|}{ No. of samples positive (percentage) } \\
\hline & & & \multicolumn{2}{|c|}{ Culture } & \multicolumn{3}{|c|}{ PCR } \\
\hline & & & MAP & Other & IS900 & ISMAP02 (1) & ISMAP02 (2) \\
\hline \multirow[t]{2}{*}{$\mathrm{H} 1$} & $11 / 2006$ & 4 & $3(75)$ & 0 & $4(100)$ & $4(100)$ & $4(100)$ \\
\hline & 05/2007 & 22 & $7(29.7)$ & 0 & $22(100)$ & $22(100)$ & $22(100)$ \\
\hline \multirow[t]{2}{*}{$\mathrm{H} 2$} & 05/2007 & 44 & $6(13.6)$ & 0 & $44(100)$ & $44(100)$ & $44(100)$ \\
\hline & $04 / 2008$ & 73 & 0 & $18(24.6)$ & 0 & 0 & $6(8.2)$ \\
\hline $\mathrm{H} 3$ & $07 / 2007$ & 35 & $5(14.3)$ & 0 & $14(40)$ & $14(40)$ & $20(57.1)$ \\
\hline $\mathrm{H} 4$ & 07/2007 & 62 & $2(3.2)$ & 0 & 21 (33.9) & 21 (33.9) & $34(54.8)$ \\
\hline $\mathrm{H} 5$ & $04 / 2008$ & 17 & 0 & $3(17.6)$ & 0 & 0 & $1(5.9)$ \\
\hline $\mathrm{H} 6$ & $04 / 2008$ & 2 & 0 & 0 & 0 & 0 & 0 \\
\hline $\mathrm{H} 7$ & $10 / 2008$ & 31 & 0 & $1(3.2)$ & 0 & 0 & $3(9.6)$ \\
\hline \multicolumn{2}{|c|}{ Total } & 290 & $23(7.9)$ & $22(7.5)$ & $105(36.2)$ & $105(36.2)$ & $134(46.2)$ \\
\hline
\end{tabular}

Data illustrating the results for each herd grouped according to PCR (IS900 \& ISMAP02), nested PCR (ISMAP02), culture and non-MAP culture. In total seven herds were sampled over the 2 year period and the number of animals sampled ranged from $2-73$. When examined collectively on a herd basis a $100 \%$ correlation was shown to exist between PCR and culture, ie the overall first round PCR results could be used to predict whether any animal in that herd would show up later as being culture positive $\left(\mathrm{H} 1,2\left[{ }^{\prime} 07\right], 3,4\right)$ or negative $\left(\mathrm{H} 2\left[{ }^{\prime} 08\right], \mathrm{H} 5, \mathrm{H} 6, \mathrm{H} 7\right)$. 
For the second batch of $\mathrm{H} 2$ samples collected 10 months later, MAP DNA was not detected, which correlates with the lack of culture positives from the same sampling period. In total, 14 and 21 DNA samples from $\mathrm{H} 3$ and $\mathrm{H} 4$ herds respectively were positive for MAP whereas all the samples from the 3 herds (H5, H6 and H7) were negative for the IS900 target.

\section{ISMAP02 PCR}

Part of this study was to evaluate the performance and reliability of molecular testing. Consequently, in order to validate the results from above, a second MAP specific DNA target was chosen (ISMAP02). As with IS900, 105 samples were PCR positive as shown in Table 2 which indicates a complete correlation between the PCR results of both targets. In summary, of the 290 individual samples tested from 7 herds over 2 years, 105 were positive for ISMAP02 PCR. 100\% of the samples in herd H1 (2006 and 2007) and H2 (2007) were ISMAP02 positive, whereas all the samples from the 3 herds (H5, H6 and H7) were negative. As seen previously for the IS900 PCR, 6, 14 and 21 DNA samples from H2 (2008), H3 and $\mathrm{H} 4$ herds were also positive for MAP respectively

\section{ISMAP02 Nested PCR}

As part of this study wished to address the threshold limits of detection for MAP DNA, a nested PCR was evaluated using ISMAP02 as a target. In total 134 of 290 samples (46\%) were positive after nested PCR. This number included 29 additional samples (10\%) which were positive only after nested PCR. Of these (29), 6, 1 and 3 ISMAP02 positive samples were detected in the herds H2 (2008), H5 and H7 respectively. Interestingly, these 3 herds were all PCR-ve based on the first round analysis of both targets. The remaining nested PCR +ve samples, (6 and 13) were identified in herds $\mathrm{H} 3$ and $\mathrm{H} 4$ respectively

To confirm the validity of the nested PCR results, DNA from the 29 additional positive samples were retested with two independent nested PCR assays namely IS900 (with alternative primers, TJ1-4) and F57. Twenty one of these samples were confirmed as being true positives after the second run of the nested IS900 and F57 assays while 8 samples (all from the same herd $\mathrm{H} 4$ ) were negative, indicating a high likelihood of false positive nested ISMAP02 PCR results among this cohort only.

\section{Discussion}

Due to the late introduction and establishment of JD in Ireland, there are relatively few publications on Paratuberculosis in this country. This study set out to evaluate a diagnostic strategy for MAP in selected Irish herds by comparing culture and molecular assays. This has relevance in terms of implementing future screening strategies for vets in Ireland and elsewhere. It is important to state that due to the logistical problems associated with obtaining samples, and the difficulty involved in enlisting willing farmers to participate, it was impossible to standardise the testing among herds in terms of obtaining equal samples from each herd. However, given this shortcoming, some important observations and conclusions can be made at the individual animal level and within each herd.

In general, we found a poor correlation between culture results from individual animals (7.9\%) and the corresponding first round PCR results (36\%). This may be due to the degree to which an animal was shedding the organism, the current disease status of the animal at the time of sampling, or the significant loss of viable cells during the harsh de-contamination step. Collectively however, it was interesting to note that all herds that tested positive by culture were also PCR positive ( $\mathrm{H} 1$, $\mathrm{H} 2, \mathrm{H} 3$ and $\mathrm{H} 4$ ) whereas the other 3 herds were negative using both methods. This is significant in terms of how PCR may be used to manage and detect Johne's disease rapidly within a herd, i.e a quick and relatively cheap PCR test from a representative number of animals could provide an early indication of the disease status of the overall herd.

Two herds were sampled twice in this study (H1 and $\mathrm{H} 2$ ) and both produced interesting results. For example, in the herd $\mathrm{H} 1$, the percentage of MAP culture-positive results varied from $75 \%$ in 2006 to $30 \%$ in 2007 (although the sample size was not comparable). In terms of Herd H2, the difference between culture and PCR results in 2007 and the same herd one year later was striking $(n=44$ and $n=0)$. This may be explained by the culling of infected animals and the possible introduction of "JD free" cattle in 2008, as seen previously by Richardson et al. (2009)[25]. It may also be explained by the selection of an alternative cohort of animals by the vets during the second visit. Due to the sensitivities involved in dealing with farmers involved in this voluntary study, limited information was made available to us regarding the degree to which the herd had been repopulated during the intervening year.

There is a significant lack of comparable studies in Ireland, and although the purpose of this project was not to draw conclusions regarding the prevalence of MAP in Ireland, it is interesting to note that our \% recovery is almost double that seen by a similar study in 2002 (O'Doherty et al. in 2002[26]. Using a similar experimental strategy this group tested 221 animals from 16 herds suspected of paratuberculosis infection and found a prevalence rate of $4.1 \%$.

As seen in other studies, the difference between the culture results in two dairy herds $(\mathrm{H} 2,13 \%$ and $\mathrm{H} 3$, 
$14 \%)$ and a beef herd (H4, 3\%) was significant. The common practice in Ireland for dairy herd managers to feed pooled colostrums and milk to calves relatively increases the risk of transmission through contaminated milk which is a significant risk factor [27].

In terms of PCR and the reliability of molecular testing, a complete correlation was observed between the results of the IS900 and ISMAP02 targets. This was surprising but not unusual as observed in a similar study [23].

The nested ISMAP02 PCR detected 29 further positive samples increasing the sensitivity of the assay by $10 \%$. However, among these additional samples, when reexamined, 8 from herd $\mathrm{H} 4$ were found negative by 2 other specific nested PCRs (IS900 and F57) based on independent triplicate results. The presence of these false positive test results may come from a single assay problem for $\mathrm{H} 4$, or may be representative of a larger reliability issue with nested PCR in this context. As well as the 8 putative false negatives, 10 of the remaining extra positives came from herds H2 (2008), H5 and H7 which were negative by both culture and first round PCR (Table 2). This may of course represent an excellent added sensitivity afforded by nested PCR for these 10 samples, or it could be indicative of potential problems with this extra test. We feel that the need for increased sensitivity must therefore be balanced with the risk of producing false positives among the results.

The presence of environmental mycobacteria ( $\mathrm{Myco-}$ bacterium non-chromogenicum and Mycobacterium terrae) within certain herds is another important finding although how it impacts on an animal's susceptibility to MAP infection is hard to assess (if at all). These mycobacteria belong to the $\mathrm{M}$. terrae complex and were originally classified as non-pathogenic saprophytes, but their pathogenic status is changing. They have been isolated from soil and are usually present in clinical samples as an environmental contaminant. Mycobacterium nonchromogenicum has also been isolated in cattle infected by bovine tuberculosis [28]. Interestingly, the 18 samples from which Mycobacterium non-chromogenicum and Mycobacterium terrae have been isolated were PCR negative for MAP DNA which indicates that these two insertion sequence IS900 and ISMAP02 are not present in these mycobacteria.

Infected animals shed MAP in milk but also in the environment where MAP persists and survives in the soil, water and sediment [29]. To minimise exposure of the human population as described previously by Hermon Taylor (2010), there is a need to understand all the potential reservoirs and all the transmission routes for MAP. If this pathogen is proven to be zoonotic, the implication for the dairy industry worldwide would be enormous [30] especially in countries like Ireland where exported milk and dairy products are significant for the national economy. It follows therefore that all countries with a paratuberculosis related problem should be working towards a rapid, standardised and reliable indicator of infection. Based on our experience, PCR should play a significant role in this.

\section{Conclusion}

In this study culturing of MAP was characterised by poor recovery $(7.9 \%)$ but high specificity. In contrast, the PCR produced faster results with improved sensitivity (36\%). The correlation between the culture and PCR result was poor at the individual animal level but in complete agreement at the herd level. Based on our experience, the choice of test employed by veterinarians should be guided by their objectives; a PCR test will produce a rapid result which may act as an "early warning" for the disease status of the herd especially if multiple animals are tested concurrently and periodically. As seen with other studies, IS900 and ISMAP02 are equally reliable as DNA targets for MAP, and the added sensitivity afforded by a nested PCR must be balanced with the potential for introducing false positive results. Despite the obvious advantages of introducing routine molecular testing for potentially infected animals, the culturing method (liquid or solid based) still remains the gold standard despite its logistical and practical limitations.

\section{Acknowledgements}

This work was financed by a grant from the Department of Agriculture from the Food Institutional Research Measure (06RDCIT414).

\section{Author details}

${ }^{1}$ Cork Institute of Technology, Bishopstown, Cork, Ireland. ${ }^{2}$ Veterinary Department, Cork County Council, County Hall, Cork, Ireland.

\section{Authors' contributions}

PED carried out the culturing, molecular analysis and drafting of the manuscript. WC and JB were the veterinarians responsible for co-ordinating the sampling, collection and transport of the faecal samples. AC and JO'M are the principal investigators and grant awardees who designed and managed the study, as well as editing the manuscript. All authors read and approved the final manuscript.

\section{Competing interests}

The authors declare that they have no competing interests.

Received: 29 July 2010 Accepted: 27 September 2010 Published: 27 September 2010

\section{References}

1. Stevenson K, Julio Alvarez Bakker JD, Biet F, Juan L, Denham S, Dimareli Z, Dohmann K, Gerlach GF, Heron I, Kopecna M, May L, Pavlik I, Sharp JM, Thibault VC, Willemsen P, Zadoks RN, Greig A: Occurrence of Mycobacterium avium subspecies paratuberculosis across host species and European countries with evidence for transmission between wildlife and domestic ruminants. BMC Microbiology 2009, 9:212.

2. Collins MT: Update on paratuberculosis: Epidemiology of Johne's disease and the biology of Mycobacterium paratuberculosis. Irish Vet Journal 2003, 56:565-574. 
3. Whittington RJ, Sergeant ES: Progress towards understanding the spread, detection and control of Mycobacterium avium subsp paratuberculosis in animal populations. Aust Vet J 2001, 79(4):267-78.

4. Hendrick SH, Kelton DF, Leslie KE, Lissemore KD, Archambault M, Duffield TF: Effect of paratuberculosis on culling, milk production, and milk quality in dairy herds. J Am Vet Med Assoc 2005, 227(8):1302-1308.

5. Losinger WC: Economic impact of reduced milk production associated with Johne's disease on dairy operations in the USA. Journal of dairy research 2005, 72(4):425-432.

6. Good M: Proceedings of conference on the role of veterinary practitioners in the control of Bovine Johne's disease 2004 Irish Department of Agriculture and Food.

7. Barrett DJ, Good M, Hayes M, More SJ: The Economic impact of Johne's disease in an Irish dairy herd: A case Study. Irish Vet Journal 2006, 59(5).

8. Good M, Clegg T, Sheridan H, Yearsely D, O'Brien T, Egan J, Mullowney P: Prevalence and distribution of paratuberculosis (Johne's disease) in cattle herds in Ireland. Irish Vet Journal 2009, 62(9):597-606.

9. Nielsen SS, Toft N: A review of prevalence of paratuberculosis in farmed animals in Europe. Preventive Veterinary Medicine 2009, 88:1-14.

10. Scanu AM, Bull TJ, Cannas S, Sanderson JD, Sechi LA, Dettori G, Zanetti S, Hermon-Taylor J: Mycobacterium avium Subspecies paratuberculosis Infection in Cases of Irritable Bowel Syndrome and Comparison with Crohn's Disease and Johne's disease: Common Neural and Immune Pathogenicities. Journal of Clinical Microbiology 2007, 45(12):3883-3890.

11. Bull TJ, McMinn EJ, Sidi-Boumedine K, Skull A, Durkin D, Neild P, Rhodes G, Pickup R, Hermon-Taylor J: Detection and Verification of Mycobacterium avium subsp. paratuberculosis in Fresh lleocolonic Mucosal Biopsy Specimens from Individuals with and without Crohn's Disease. J Clin Microbiol 2003, 41:2915-2923.

12. Sibartie S, Scully P, Keohane J, O'Neill S, O'Mahony J, O'Hanlon D, Kirwan WO, O'Mahony L, Shanahan F: Mycobacterium avium subsp. Paratuberculosis (MAP) as a modifying factor in Crohn's disease. Inflamm Bowel Dis 2010, 16(2):296-304.

13. Hermon-Taylor J: Mycobacterium avium subspecies paratuberculosis, Crohn's disease and the doomsday scenario. Gut Pathogens 2010, 1:15.

14. Ryan T, Campbell D: Mycobacterium paratuberculosis - A Public Health Issue? New Zealand Food Safety Authority 2006.

15. Millar D, Ford J, Sanderson J, Withey S, Tizard M, Doran T, Hermon-Taylor J: IS900 PCR to detect Mycobacterium paratuberculosis in retail supplies of whole pasteurized cows' milk in England and Wales. Appl Environ Microbiol 1996, 62(9):3446-52.

16. Grant IR, Ball HJ, Rowe MT: Incidence of Mycobacterium paratuberculosis in bulk raw and commercially pasteurized cows' milk from approved dairy processing establishments in the United Kingdom. Applied and Environmental microbiology 2002, 68(5):2428-2435.

17. Mutharia LM, Klassen MD, Fairles J, Barbut S, Gill CO: Mycobacterium avium subsp. paratuberculosis in muscle, lymphatic and organ tissues from cows with advanced Johne's disease. International Journal of Food Microbiology 2010, 136:340-344.

18. Ristow P, Silva MG, Fonseca LS, Lilenbaum W: Evaluation of Mycobacterium avium subsp. paratuberculosis faecal culture protocols and media. Pesq Vet Bras 2006, 26(1):1-4.

19. Nieminen T, Pakarinen J, Tsitko I, Salkinoja-Salonen M, Breitenstein A, AliVehmas T, Neubauer P: $16 \mathrm{~S}$ rRNA targeted sandwich hybridization method for direct quantification of mycobacteria in soils. Journal of Microbiological Methods 2006, 67:44-55.

20. Semret M, Turenne CY, Haas P, Collins DM, Behr MA: Differentiating hostassociated variants of Mycobacterium avium by PCR for detection of large sequence polymorphisms. Journal of Clinical Microbiology 2006, 44(3):881-887.

21. O'Mahony J, Hill C: Rapid real-time PCR assay for detection and quantitation of Mycobacterium avium subsp. Paratuberculosis DNA in artificially contaminated milk. Appl Environ Microbiol 2004, 2070(8):4561-8.

22. O'Mahony J, Hill C: A real-time PCR assay for the detection and quantitation of Mycobacterium avium subsp. paratuberculosis using SYBR Green and the Light Cycler. Journal of Microbiological Methods 2002, 51:283-293.

23. Stabel JR, Bannantine JP: Development of a nested PCR method targeting a unique multicopy element, ISMap02, for detection of Mycobacterium avium subsp. paratuberculosis in fecal samples. Journal of Clinical Microbiology 2005, 43(9):4744-4750.
24. Vansnick E, Rijk P, Vercammenc F, Geysen D, Rigouts L, Portaels F: Newly developed primers for the detection of Mycobacterium avium subspecies paratuberculosis. Veterinary Microbiology 2004, 100:197-204.

25. Richardson EKB, More SJ: Direct and indirect effects of Johne's disease on farm and animal productivity in an Irish dairy herd. Irish Veterinary Journal 2009, 62(8):526-532.

26. O' Doherty A, O'Grady D, O'Farrell K, Smith T, Egan J: Survey of Johne's disease in imported animals in the Republic of Ireland. Vet Rec 2002, 18:634-636.

27. Cashman W, Buckley J, Quigley T, Fanning S, More S, Egan J, Berry D, Grant I, O' Farrell K: Risk factors for the introduction and within-herd transmission of Mycobacterium avium subspecies paratuberculosis (MAP) infection on 59 Irish dairy herds. Irish Veterinary Journal 2008, 61(7).

28. McCorry TP, McCormick CM, Hughes MS, Pollock JM, Neill SD: Mycobacterium nonchromogenicum in nasal mucus from cattle in a herd infected with bovine tuberculosis. Veterinary Microbiology 2004, 99:281-285.

29. Whittington RJ, Marsh IB, Reddacliff LA: Survival of Mycobacterium avium subsp. paratuberculosis in Dam Water and Sediment. Applied and environmental Microbiology 2005, 71(9):5304-5308.

30. Groenendaal H, Zagmutt FJ: Scenario analysis of changes in consumption of dairy products caused by a hypothetical causal link between Mycobacterium avium subspecies paratuberculosis and Crohn's Disease. J Dairy Science 2008, 91:3245-3258.

doi:10.1186/1757-4749-2-11

Cite this article as: Douarre et al.: Isolation and detection of Mycobacterium avium subsp. paratuberculosis (MAP) from cattle in Ireland using both traditional culture and molecular based methods. Gut Pathogens 2010 2:11.

\section{Submit your next manuscript to BioMed Central and take full advantage of:}

- Convenient online submission

- Thorough peer review

- No space constraints or color figure charges

- Immediate publication on acceptance

- Inclusion in PubMed, CAS, Scopus and Google Scholar

- Research which is freely available for redistribution

Submit your manuscript at www.biomedcentral.com/submit
C Biomed Central 